\title{
PENGARUH SUBSTITUSI ALGA Nannochloropsis oculata DENGAN PAKAN BUATAN DALAM BUDI DAYA ROTIFER (Brachionus plicatilis)
}

\author{
Yunus" dan Ketut Suwirya
}

\begin{abstract}
ABSTRAK
Budi daya rotifer umumnya menggunakan pakan berupa fitoplankton. Karena kesulitan dalam penyediaan fitoplankton secara massal dan tepat waktu diperlukan upaya ke arah penggunaan jenis pakan lain, seperti pakan buatan untuk budi daya rotifer. Percobaan ini bertujuan untuk mengetahui pengaruh pemberian pakan buatan untuk budi daya rotifer. Budi daya rotifer dilakukan dalam bak polikarbonat dengan volume 30 liter dengan kepadatan awal rotifer 200 ind./mL. Percobaan menggunakan rancangan acak lengkap dengan tiga taraf perlakuan, yaitu rotifer yang diberi pakan buatan dengan frekuensi pemberian dua dan tiga kali sehari serta rotifer yang diberi pakan alga Nannochloropsis oculata sebagai kontrol. Setiap perlakuan diulang tiga kali. Rotifer dibudidayakan dengan cara panen $50 \%$ per hari. Percobaan berlangsung sampai dengan hari ke empat. Hasil penelitian menunjukkan pengaruh yang tidak nyata antar perlakuan $(\mathrm{P}>0,05)$ terhadap rata-rata kepadatan rotifer sebelum dipanen, jumlah telur yang dihasilkan dan ukuran rotifer. Pakan buatan dapat diaplikasikan penggunaannya dalam budi daya rotifer (B. plicatilis) dengan frekuensi pemberian 2 kali/hari. Namun demikian rotifer hasil panen sebelum digunakan sebagai pakan alami sebaiknya diperkaya dengan asam lemak untuk meningkatkan nilai gizinya.
\end{abstract}

ABSTRACT: Effect of substitute of Nannochloropsis oculata with artificial feed for rotifer (Brachionus plicatilis) culture. By: Yunus and Ketut Suwirya.

Phytoplankton is the most popular food for the culture of rotifer. However, due to some difficulties in mass production of phytoplankton to meet the demand, the utilization of other types of food such as artifial feed was taken into consideration. Experiment was conducted with the objective of assessing the effect of artificial feed in rotifer culture. Rotifer was reared in 30 liter polycarbonat tanks at an initial density of $200 \mathrm{ind} . / \mathrm{mL}$. Three treatments arranged in a completely randomized design with three replicates each were applied, i.e, rotifer fed with artificial feed at 2 and 3 times per day and rotifer fed Nannochloropsis oculata as a control. Rotifer was cultured by $50 \%$ harvesting method per day. The culture experiment was terminated at the fourth day. The results revealed that there were no differences among treatments $(P>0.05)$ on the average density of rotifers before harvested, the average number of eggs yielded and the size of rotifers. The artificial feed could be used as a diet for culturing rotifer (B. plicatilis) with feeding frequency of 2 times/day. Dietary value of harvested rotifers is recommended to be improved by enriching with essential fatty acid before being utilized as live food.

KEYWORDS: Nannochloropsis oculata, artificial feed, rotifer culture.

\section{PENDAHULUAN}

Rotifer (Brachionus plicatilis) merupakan zooplankton yang mempunyai peranan penting untuk digunakan sebagai makanan hidup bagi beberapa spesies ikan laut yang dibudidayakan. Sudah sejak lama jenis rotifer digunakan sebagai pakan larva ikan buntal (Fugu rubripes rubripes) di Jepang (Hirata, 1964). Oka (1967) mendapatkan hasil pertumbuhan yang lebih cepat dan tingkat sintasan yang lebih tinggi dari larva Penaeus orientalis yang dipelihara dengan diberi pakan rotifer. Hudinaga \& Kittaka (1966) menggunakan jenis rotifer ini untuk pakan larva Penaeus japonicus. Beberapa dekade berikutnya, Purba (1995) menemukan bahwa rotifer merupakan pakan yang paling baik bagi larva ikan kerapu macan (Epinephelus fuscoguttatus) yang baru mulai makan. Selanjutnya diketahui (Redjeki et al., 1993; Aslianti et al., 1993) bahwa jenis rotifer ini juga merupakan pakan yang baik bagi larva ikan kakap putih (Lates calcarifer) dan larva ikan bandeng (Chanos chanos). Penggunaan rotifer memberikan hasil yang baik pula pada pemeliharaan larva kepiting batu (Menippe merceneria) pada masa stadia awal (Yang, 1971) dan larva kepiting bakau (Scylla serrata) (Brick, 1974; Motoh et al., 1977; Yunus et al., 1996).

"Peneliti pada Loka Penelitian Perikanan Pantai Gondol 
Budi daya rotifer dapat dilakukan dengan menggunakan pakan berupa fitoplankton. Jenis fitoplankton yang digunakan Hirata \& Mori (1967) untuk budi daya rotifer adalah Chlorella spp. dan Dunaliella spp., sedangkan yang digunakan Theilacker \& Mc Master (1971) adalah Monochrysis lutheri, Nannochloris spp. dan Dunaliella spp. Jenis fitoplankton lainnya yang dapat dipakai sebagai makanan rotifer adalah Tetraselmis spp. dan Nannochloropsis oculata (Griffith et al., 1973; Sutarmat \& Ismi, 1996).

Budi daya rotifer secara massal dengan menggunakan pakan berupa alga $N$. oculata telah dikembangkan di Yashima Station, Jepang pada tahun 1964 (Hirata, 1979). Penggunaan jenis alga ini dalam kegiatan budi daya rotifer juga dilakukan di Finfish Program, Oceanic Institute, Hawaii (Sato, 1991), di Sung-Ji Industry, Korea Selatan (Pie, 1991), di panti benih ikan di Thailand dan Singapura (Kongkeo, 1991; Lim, 1991). Di Indonesia budi daya rotifer dengan menggunakan alga $N$. oculata telah banyak dilakukan di panti benih ikan bandeng (Ahmad et al., 1994; Sumiarsa et al., 1994).

Penggunaan alga dalam budi daya rotifer selain memerlukan fasilitas tempat dan wadah, juga membutuhkan tenaga kerja dan waktu untuk penumbuhan alga sebagai sediaan makanan untuk rotifer. Sebagai contoh, untuk budi daya rotifer dengan volume $500 \mathrm{~L}$ diperlukan volume alga sebanyak 5-10 kali volume rotifer tersebut atau sebanyak 2500-5000 L (Hirata, 1980 dalam Lubzens, 1987). Karena produksi alga sedikit banyak tergantung pada keadaan cuaca, maka kontinuitas penyediaan alga sebagai pakan rotifer seringkali tidak mantap.

Oleh karena itu perlu upaya ke arah penggunaan jenis pakan lain untuk rotifer seperti yang dilakukan oleh Hirata \& Mori (1967) yang menganjurkan penggunaan khamir roti sebagai pakan rotifer. Kawano (1968) mengemukakan bahwa khamir laut (Zygosaccharomyces marinus) merupakan pakan yang baik bagi rotifer. Hasil penelitian Hirayama \& Watanabe (1972) tentang penggunaan khamir Rhodotorula sp. dan khamir laut komersial (ASY-4011) menyimpulkan bahwa khamir dapat digunakan secara efektif sebagai pakan tambahan untuk rotifer apabila sediaan fitoplankton tidak mencukupi. Namun demikian Kitajima et al. (1979) melaporkan bahwa rotifer hasil budi daya dengan khamir saja dapat menyebabkan terjadinya mortalitas yang tinggi apabila rotifer tersebut diberikan kepada larva ikan sebagai akibat dari rendahnya nilai gizi rotifer. Oleh sebab itu khamir harus ditingkatkan nilai gizinya dengan dicampur bahan pakan yang lain dan diberikan kepada rotifer sebagai pakan buatan.

Penggunaan pakan buatan dalam budi daya rotifer tidak memerlukan fasilitas seperti pada penggunaan alga, sehingga hal ini dapat mening. katkan efisiensi. Selain itu pakan buatan mudah dalam proses pemberiannya sebagai pakan pada rotifer dan karena pakan buatan mudah disimpan maka budi daya rotifer dapat dilakukan setiap saat.

Percobaan ini bertujuan untuk mengetahui pengaruh substitusi alga $N$. oculata sebagai pakan alami bagi rotifer dengan pakan buatan.

\section{BAHAN DAN METODE}

Percobaan dilakukan di Laboratorium Loka Penelitian Perikanan Pantai Gondol, Bali dengan menggunakan hewan uji rotifer (Brachionus plicatilis) tipe S. Bak polikarbonat dengan volume air media $30 \mathrm{~L}$ sebanyak 9 buah yang dilengkapi aerasi digunakan untuk budi daya rotifer dengan kepadatan awal 200 ind./mL. Selama penelitian rotifer diberi pakan buatan dengan komposisi bahan baku seperti yang tercantum dalam Tabel 1. Jenis khamir yang digunakan adalah Saccharomyces cerevisiae.

Metode pembuatan pakan mengikuti Kanazawa (1985a). Semua bahan baku tersebut sebanyak 300 g dengan ditambah $500 \mathrm{~mL}$ etanol 70\% dicampurkan menjadi satu dengan blender merk Waring, model 31BL92. Penambahan etanol dimaksudkan untuk mengaktifkan zein karena pakan ini menggunakan zein sebagai binder. Selanjutnya adonan dimasukkan ke dalam oven selama 2 jam pada suhu $90^{\circ} \mathrm{C}$. Setelah kering adonan dihaluskan dan disaring sebanyak dua kali dengan menggunakan saringan yang berbeda, masing-masing berdiameter mata 70 dan $50 \mu \mathrm{m}$. Hasil saringan merupakan pakan yang diberikan kepada rotifer dengan dosis $1 \mathrm{~g} / 10^{6}$ individu rotifer/hari. Pakan percobaan mempunyai kadar protein dan lemak masing-masing sebesar 38,17 dan 7,65\%.

Rancangan percobaan yang digunakan adalah rancangan acak lengkap dengan tiga taraf perlakuan, yaitu rotifer yang diberi pakan buatan dengan frekuensi pemberian 2 kali/hari (A) dan 3 kali/hari (B) serta rotifer yang diberi pakan alga Nannochloropsis oculata $10^{7} \mathrm{sel} / \mathrm{mL} /$ hari sebagai kontrol (C), masing-masing diulang tiga kali. Pemberian pakan buatan dilakukan setelah penghitungan jumlah rotifer dan jumlah pakan disesuaikan dengan jumlah rotifer. Adapun alga ditambahkan setiap hari sehingga mencapai kepadatan semula sesuai dengan ketentuan. 
Tabel 1. Komposisi bahan baku pakan buatan yang digunakan dalam penelitian. Table 1. Composition of raw materials of artificial feed used in the experiment.

\begin{tabular}{lc}
\hline \multicolumn{1}{c}{$\begin{array}{c}\text { Bahan } \\
\text { Ingredient }\end{array}$} & $\begin{array}{c}\text { Persentase } \\
\text { Percentage }\end{array}$ \\
\hline Khamir (Yeast) & 40 \\
Tepung rebon (Mysid shrimp meal) & 10 \\
Tepung ikan (Fish meal) & 5 \\
Tepung beras (Rice flour) & 20 \\
Tepung kanji (Tapioca flour) & 8 \\
Vitamin mix & 2 \\
Mineral mix & 3 \\
Minyak hati ikan cod (Cod liver oil) & 4 \\
Zein & 8 \\
\hline
\end{tabular}

Budi daya rotifer dilakukan dengan sistem panen harian sebanyak $50 \%$ dari volume air media pemeliharaan. Pada mulanya bak diisi air laut yang telah disaring dengan kantong filter dan ditambah pakan buatan sesuai perlakuan, sedangkan untuk kontrol, bak hanya diisi dengan air alga sebagai media pemeliharaan. Selanjutnya bak diaerasi dan ditebar rotifer. Hari berikutnya rotifer dipanen dengan cara mengeluarkan 50\% volume air media dari bak. Air media yang dikeluarkan tersebut kemudian disaring menggunakan jaring plankton berukuran $60 \mu \mathrm{m}$ sehingga rotifer dapat tertampung dalam saringan tersebut. Selesai panen, ke dalam bak ditambahkan air media baru hingga mencapai volume semula sebagai persiapan untuk panen rotifer pada hari berikutnya lagi dengan cara yang sama seperti sebelumnya. Penelitian berlangsung sampai hari ke empat.

Pengambilan sampel untuk penghitungan kepadatan populasi rotifer, jumlah telur rotifer dan alga dilakukan setiap hari. Jumlah rotifer, telur rotifer dan alga dihitung di bawah mikroskop merk Microstar IV, model No. $410 \mathrm{~V}$, dengan menggunakan sedgewick rafter counting chamber untuk rotifer atau telur rotifer dan haemacytometer untuk alga. Pengukuran tubuh rotifer (panjang dan lebar lorica) dilakukan di bawah mikroskop dengan menggunakan mikrometer. Rotifer hasil panen dari masing-masing perlakuan setelah dicuci bersih dikeringkan pada suhu $-50^{\circ} \mathrm{C}$ dengan alat vacuum freeze dryer dan selanjutnya dianalisis untuk menentukan kadar protein, lemak, air, dan komposisi asam lemak dengan metode dari SEAFDEC (Anonim, 1978). Analisis asam lemak menggunakan alat gas kromatografi merk Antek 3000, panjang kolom $2 \mathrm{~m}$ dan diameter 1/8 inci dengan kondisi kolom: OV-275 $\left(190-230^{\circ} \mathrm{C}\right)$, detektor: FID $\left(250^{\circ} \mathrm{C}\right)$, kecepatan gas pendorong: $\mathrm{N}_{2}, 30 \mathrm{~mL} / \mathrm{menit}$ dan suhu injektor $250^{\circ} \mathrm{C}$. Sebagai penunjang dilakukan pengamatan terhadap kualitas air media pemeliharaan.

\section{HASIL DAN BAHASAN}

Hasil pengamatan kepadatan rotifer sebelum dipanen, jumlah telur serta ukuran (panjang dan lebar lorica) rotifer selama empat hari pemeliharaan masing-masing disajikan pada Tabel 2, 3 dan 4. Berdasarkan analisis statistik ternyata kepadatan rotifer tidak menunjukkan perbedaan yang nyata antar perlakuan $(\mathrm{P}>0,05)$ (Tabel 2). Pada Tabel 3 dapat dilihat jumlah telur rata-rata yang dihasilkan rotifer tidak menunjukkan perbedaan yang nyata antar perlakuan $(\mathrm{P}>0,05)$, namun pada hari ke empat nilai tertinggi dicapai pada frekuensi pemberian pakan buatan 2 kali/ hari dan berbeda nyata $(\mathrm{P}<0,05)$ dengan perlakuan yang lain. Pada Tabel 4 terlihat bahwa perlakuan pakan buatan dan kontrol tidak menunjukkan perbedaan yang nyata $(P>0,05)$ terhadap ukuran rotifer, baik panjang maupun lebar lorica.

Nilai gizi makanan pada umumnya dilihat dari komposisi nutriennya seperti kandungan protein, lemak, kadar air, serat kasar dan kadar abu (Hariati, 1989 dalam Anwar, 1996). Hasil analisis kandungan nutrien alga $N$. oculata menunjukkan kandungan protein dan lemak masing-masing sebesar 23,1 dan 7,53\% (Anwar, 1996), sedangkan kandungan protein dan lemak pakan buatan pada penelitian ini masing-masing adalah 38,17 dan 7,65\%. Ditinjau dari segi komposisi nutrien, kandungan protein pakan buatan menunjukkan nilai yang lebih tinggi dibanding dengan protein alga $N$. oculata. Tingginya protein pakan buatan tampaknya belum berpengaruh terhadap nilai 
Tabel 2. Kepadatan rotifer (B. plicatilis) (individu/mL) sebelum dipanen dari setiap perlakuan selama empat hari pemeliharaan.

Table 2. Density of rotifer (B. plicatilis) (individu/ $m L$ ) before harvested from each treatment during 4 days culture.

\begin{tabular}{|c|c|c|c|c|c|c|}
\hline \multirow{2}{*}{$\begin{array}{l}\text { Perlakuan } \\
\text { Treatment }\end{array}$} & \multicolumn{5}{|c|}{ Hari (Day) } & \multirow{2}{*}{$\begin{array}{c}\text { Rata-rata } \\
\text { Average }\end{array}$} \\
\hline & 0 & 1 & 2 & 3 & 4 & \\
\hline A & 200 & $483 \pm 126^{\mathrm{a}}$ & $300 \pm 50^{\mathrm{a}}$ & $317 \pm 29^{a}$ & $200 \pm 100^{\mathrm{a}}$ & $325 \pm 33^{\mathrm{a}}$ \\
\hline B & 200 & $333 \pm 126^{a}$ & $383 \pm 104^{a}$ & $283 \pm 104^{a}$ & $180 \pm 53^{\mathrm{a}}$ & $295 \pm 89^{a}$ \\
\hline $\mathrm{C}$ & 200 & $283 \pm 104^{a}$ & $350 \pm 100^{\mathrm{a}}$ & $200 \pm \quad 0^{a}$ & $130 \pm 17^{\mathrm{a}}$ & $241 \pm 20^{a}$ \\
\hline
\end{tabular}

$\mathrm{A}=$ Pakan buatan $2 \mathrm{kali} /$ hari (Artificial feed, 2 times/day)

$\mathrm{B}=$ Pakan buatan $3 \mathrm{kali} /$ hari (Artificial feed, 3 times $/$ day)

$\mathrm{C}=$ Nannochloropsis oculata

Angka dalam kolom diikuti huruf superskrip yang sama tidak berbeda nyata (Values in column followed by the same superscript are not significantly different) $(\mathrm{P}>0.05)$.

Tabel 3. Jumlah telur (butir/mL) yang dihasilkan rotifer (B. plicatilis) dari setiap perlakuan selama empat hari pemeliharaan.

Table 3. Number of eggs (pcs $/ \mathrm{mL}$ ) yielded by rotifer (B. plicatilis) from each treatment during 4 days culture.

\begin{tabular}{|c|c|c|c|c|c|}
\hline \multirow{2}{*}{$\begin{array}{l}\text { Perlakuan } \\
\text { Treatment }\end{array}$} & \multicolumn{4}{|c|}{ Hari (Day) } & \multirow{2}{*}{$\begin{array}{c}\text { Rata-rata } \\
\text { Average }\end{array}$} \\
\hline & 1 & 2 & 3 & 4 & \\
\hline A & $250 \pm 100^{\mathrm{a}}$ & $333 \pm 208^{a}$ & $217 \pm 58^{2}$ & $117 \pm 29^{\mathrm{a}}$ & $229 \pm 83^{a}$ \\
\hline B & $167 \pm 104^{\mathrm{a}}$ & $167 \pm 161^{\mathrm{a}}$ & $317 \pm 89^{a}$ & $27 \pm 12^{\mathrm{b}}$ & $169 \pm 77^{\mathrm{a}}$ \\
\hline $\mathrm{C}$ & $150 \pm 50^{\mathrm{a}}$ & $133 \pm 76^{\mathrm{a}}$ & $183 \pm 29^{a}$ & $50 \pm 0^{\mathrm{b}}$ & $129 \pm 38^{\mathrm{a}}$ \\
\hline
\end{tabular}

$\mathrm{A}=$ Pakan buatan, $2 \mathrm{kali} / \mathrm{hari}$ (Artificial feed, 2 times $/$ day)

$\mathrm{B}=$ Pakan buatan, $3 \mathrm{kali} / \mathrm{hari}$ (Artificial feed, 3 times $/$ day)

$\mathrm{C}=$ Nannochloropsis oculata

Angka dalam kolom diikuti huruf superskrip yang sama tidak berbeda nyata (Values in column followed by the same superscript are not significantly different $)(\mathrm{P}>0.05)$.

kepadatan rotifer yang dalam kenyataannya terlihat bahwa kepadatan rotifer (harian dan ratarata) antara pakan buatan dan alga tidak berbeda nyata. Namun demikian tingginya protein pakan buatan diduga berpengaruh terhadap jumlah telur yang dihasilkan rotifer yang menunjukkan angka tertinggi pada pemberian pakan buatan $2 \mathrm{kali} / \mathrm{hari}$ pada hari ke empat dan berbeda nyata dengan yang diberi pakan alga. Protein yang terkandung dalam pakan mempunyai peranan yang sangat penting untuk pertumbuhan dan pemeliharaan tubuh organisme (Kanazawa, 1985b). Pada ikan diperlukan secara teratur pemanfaatan protein dari pakan karena protein secara terus-menerus digunakan oleh ikan untuk proses pertumbuhan dan reproduksi serta pemeliharaan tubuh (Wilson, 1989).
Kandungan lemak pada pakan buatan dan alga menunjukkan nilai yang hampir sama dan diduga hal ini yang menyebabkan ukuran rotifer baik panjang maupun lebar lorica antara yang diberi pakan buatan dan alga tidak berbeda nyata. Dengan demikian penggunaan pakan buatan ternyata tidak menyebabkan terjadinya proses penggemukan rotifer.

Hasil analisis protein, lemak dan asam lemak dari rotifer disajikan pada Tabel 5 . Kadar protein dan lemak rotifer yang diberi pakan buatan dan pakan alga tidak berbeda nyata $(P>0,05)$.

Kandungan asam lemak eikosapentaenoat (20:5n-3), dokosaheksaenoat (22:6n-3) dan total asam lemak $n$-3 berantai rangkap jamak (HUFA) rotifer yang diberi pakan alga ternyata menunjuk- 
Tabel 4. Ukuran (panjang dan lebar lorica) $(\mu \mathrm{m})$ rotifer (B. plicatilis) dari setiap perlakuan selama empat hari pemeliharaan.

Table 4. Size (length and width of lorica) $(\mu \mathrm{m})$ of rotifer (B. plicatilis) from each treatment during 4 days rulture.

\begin{tabular}{|c|c|c|c|c|c|c|c|c|c|c|}
\hline \multirow{2}{*}{$\begin{array}{l}\text { Perlakuan } \\
\text { Treatment }\end{array}$} & \multicolumn{2}{|c|}{$\begin{array}{c}\text { Hari }(D a y) \\
1\end{array}$} & \multicolumn{2}{|c|}{$\begin{array}{c}\text { Hari (Day) } \\
\mathbf{2}\end{array}$} & \multicolumn{2}{|c|}{$\begin{array}{c}\text { Hari (Day) } \\
3\end{array}$} & \multicolumn{2}{|c|}{$\underset{4}{\text { Hari }}$} & \multicolumn{2}{|c|}{$\begin{array}{l}\text { Rata-rata } \\
\text { Average }\end{array}$} \\
\hline & $P$ & L & $\mathbf{P}$ & $\mathbf{L}$ & $\mathbf{P}$ & $\mathbf{L}$ & $\mathbf{P}$ & $\mathrm{L}$ & $\mathbf{P}$ & $\mathrm{L}$ \\
\hline A & $174 \pm 9^{3}$ & $111 \pm 11^{a}$ & $177 \pm 6^{\mathrm{a}}$ & $130 \pm 9^{\mathrm{a}}$ & $176 \pm 12^{\mathrm{a}}$ & $115 \pm 8$ & $173 \pm 14^{\prime}$ & $116 \pm 16^{\mathrm{a}}$ & $175 \pm 6^{\mathrm{i}}$ & $118 \pm 8$ \\
\hline $\mathrm{B}$ & $164 \pm 5^{i 1}$ & $106 \pm 19^{7}$ & $189 \pm 7^{\mathrm{a}}$ & $137 \pm 13^{\mathrm{a}}$ & $159 \pm 19^{\mathrm{a}}$ & $107 \pm 13^{2}$ & $165 \pm 14^{\prime \prime}$ & $112 \pm 4^{2}$ & $169 \pm 8^{a}$ & $116 \pm 3^{2}$ \\
\hline C & $175 \pm 5$ & $97 \pm 12^{\mathrm{a}}$ & $183 \pm 4^{\mathrm{a}}$ & $127 \pm 5^{\mathrm{a}}$ & $175 \pm 18^{\mathrm{a}}$ & $129 \pm 8$ & $169 \pm 9^{a}$ & $123 \pm 8^{a}$ & $176 \pm 5^{a}$ & $119 \pm 3^{\mathrm{a}}$ \\
\hline
\end{tabular}

$\mathrm{A}=$ Pakan buatan, $2 \mathrm{kali} / \mathrm{hari}$ (Artificial feed, 2 times $/$ day)

$\mathrm{B}=$ Pakan buatan, $3 \mathrm{kali} / \mathrm{hari}$ (Artificial feed, 3 times/day)

$\mathrm{C}=$ Nannochloropsis oculata

$\mathrm{P}=$ Panjang $($ Length $)$

$\mathrm{L}=$ Lebar $($ Width)

Angka dalam kolom diikuti huruf superskrip yang sama tidak berbeda nyatid (Values in column followed by the same superscript are not significantly' different) $(\mathrm{P}>0.05)$

Tabel 5. Kandungan protein, lemak dan air serta profil asam lemak yang terkandung dalam rotifer (B. plicatilis) dari setiap perlakuan.

Table 5. Protein, lipid and moisture contents as well as fatty acids profiles of rotifer ( $\boldsymbol{B}$. plicatilis) from each treatment.

\begin{tabular}{lccc}
\hline \multirow{2}{*}{$\begin{array}{c}\text { Parameter analisis } \\
\text { Analytical parameter }\end{array}$} & \multicolumn{3}{c}{ Perlakuan (Treatment) } \\
\cline { 2 - 4 } & A & B & C \\
\hline Protein (\%) & $62.81^{\mathrm{a}}$ & $65.87^{\mathrm{a}}$ & $59.96^{\mathrm{a}}$ \\
Lemak (Lipid) (\%) & $8.24^{\mathrm{a}}$ & $8.83^{\mathrm{a}}$ & $8.88^{\mathrm{a}}$ \\
Kadar air (Moisture) (\%) & $7.00^{\mathrm{a}}$ & $6.22^{\mathrm{a}}$ & $6.53^{\mathrm{a}}$ \\
Asam lemak (Fatty acid) (\%) & & & \\
14:0 & 3.73 & 4.08 & 4.94 \\
$16: 0$ & 13.92 & 15.51 & 20.51 \\
$16: 1$ & 19.79 & 20.57 & 22.11 \\
$18: 0$ & 3.27 & 3.25 & 2.59 \\
$18: 1$ & 23.2 & 24.38 & 12.83 \\
$18: 2 \mathrm{n}-6$ & 17.85 & 16.18 & 6.13 \\
18:3n-3 & 2.57 & 2.38 & 2.02 \\
$20: 1 \mathrm{n}-9$ & 0.44 & 0.54 & - \\
$20: 2 \mathrm{n}-6$ & 0.73 & - & - \\
$20: 3 \mathrm{n}-3$ & 1.73 & 2.37 & 4.27 \\
$20: 5 \mathrm{n}-3$ & $2.36^{\mathrm{a}}$ & $2.47^{\mathrm{a}}$ & $13.02^{\mathrm{b}}$ \\
$22: 6 \mathrm{n}-3$ & $1.45^{\mathrm{a}}$ & $1.04^{\mathrm{a}}$ & $5.00^{\mathrm{b}}$ \\
Total $\mathrm{n} 3$ berikatan rangkap jamak & & & \\
(HUFA) & $8.11^{\mathrm{a}}$ & $8.26^{\mathrm{a}}$ & $24.13^{\mathrm{b}}$ \\
\hline
\end{tabular}

$\mathrm{A}=$ Pakan buatan, $2 \mathrm{kali} / \mathrm{hari}$ (Artificial feed, 2 times $/$ day)

$\mathrm{B}=$ Pakan buatan, $3 \mathrm{kali} / \mathrm{hari}$ (Artificial feed, 3 times/day)

$\mathrm{C}=$ Nannochloropsis oculata

Angka dalam kolom diikuti huruf superskrip yang sama tidak berbeda nyata (Values in column followed by the same superscript are not significantly different) $(\mathrm{P}>0.05)$ 
kan nilai tertinggi dan berbeda nyata $(\mathrm{P}<0,05)$ dengan yang diberi pakan buatan. Sebagaimana diketahui bahwa asam lemak esensial seperti eikosapentaenoat (EPA) dan dokosaheksaenoat (DHA) sangat diperlukan bagi pertumbuhan dan sintasan larva ikan dan krustase (Watanabe et al., 1983; Kanazawa et al., 1985; Lubzens, 1987).

Pada penelitian ini rotifer yang diberi pakan buatan mempunyai nilai EPA dan DHA sebesar 2,36-2,47 dan 1,04-1,45\%. Nilai ini masih lebih tinggi dibandingkan nilai EPA dan DHA rotifer yang dibudi daya dengan khamir roti (1,0 dan 0,1\%) (Watanabe et al., 1984 dalam Redjeki et al., 1993), Tetraselmis spp. (1,27 dan 0\%) (Pechmanee \& Assavaaree, 1993), T. tetrathele (0,52 dan 0,08\%) (Tamaru et al., 1991) dan khamir roti + Chlorella vulgaris (0,6 dan 0\%) (Villegas, 1990).

Namun demikian, karena nilai EPA dan DHA rotifer yang diberi pakan buatan lebih rendah dibandingkan yang diberi pakan alga (Tabel 5), maka kandungan asam lemak esensial rotifer pada perlakuan pakan buatan tersebut masih perlu ditingkatkan lagi.

Oleh karena rotifer mudah diperkaya dengan asam lemak (Lubzens et al., 1989) maka peningkatan gizi rotifer dapat dilakukan dengan menginkubasi rotifer dalam larutan bahan pengkaya tertentu selama beberapa saat sebelum digunakan sebagai pakan alami. Pengkayaan rotifer merupakan salah satu usaha untuk meningkatkan kualitas rotifer (Sumiarsa et al., 1996). Aslianti (1994) menyatakan bahwa penggunaan minyak ikan, spirulina kering dan dryselco sebagai bahan pengkaya rotifer dalam ransum pakan larva bandeng menghasilkan vitalitas larva yang lebih baik. Dosis bahan pengkaya yang digunakan adalah $0,4 \mathrm{~g} / \mathrm{L}$ dengan kepadatan rotifer sebanyak 5-20 ind./mL dan lama pengkayaan 12 jam. Menurut Purba (1995) penggunaan bahan pengkaya berupa minyak hati ikan cod dapat meningkatkan nilai gizi rotifer yang lebih baik dibanding minyak ikan lain atau alga laut. Bahan pengkaya rotifer yang digunakan dalam penelitian tersebut adalah 5 g minyak hati ikan cod ditambah $1 \mathrm{~g}$ kuning telur ayam dan $12 \mathrm{~g}$ ragi roti dalam $100 \mathrm{~L}$ media air laut dengan kepadatan rotifer sebanyak 20-25 juta individu dan lama pengkayaan 6-12 jam.

Hasil pengamatan kualitas air menunjukkan bahwa $\mathrm{pH}$, nitrit dan amonia masing-masing dalam kisaran 7,16-7,30;0,082-0,306 mg/L dan 0,950-3,377 $\mathrm{mg} / \mathrm{L}$. Kandungan amonia tertinggi terdapat pada perlakuan pakan buatan yang diduga disebabkan adanya proses dekomposisi bahan organik yang berasal dari sisa pakan buatan tersebut. Rotifer (B. plicatilis) mempunyai toleransi yang tinggi terhadap a monia dan rotifer masih tahan hidup dengan konsentrasi amonia mencapai 6-10 mg/L (Fulks \& Main, 1991).

\section{KESIMPULAN}

1. Perlakuan pakan buatan dan alga memberikan pengaruh yang sama terhadap rata-rata kepadatan rotifer sebelum dipanen, jumlah telur yang dihasilkan dan ukuran rotifer.

2. Pakan buatan dalam percobaan ini dapat diaplikasikan penggunaannya dalam budi daya rotifer (B. plicatilis) dengan frekuensi pemberian 2 kali/hari.

3. Untuk meningkatkan nilai gizinya, rotifer dapat diperkaya dengan asam lemak.

\section{DAFTAR PUSTAKA}

Ahmad, T., Aslianti, T. dan Rohaniawan, D. 1994. Laju pertumbuhan dan kelangsungan hidup nener, Chanos chanos dalam berbagai nuansa warna wadah. J. Penel. Budidaya Pantai 10(1):123-134.

Anonim. 1978. Laboratory Manual for the Analysis of Water, Feeds and Feed Ingredients. Centralized Analytical Laboratory, Tigbauan Research Station, Aquacult. Dept. SEAFDEC Tigbauan, Iloilo, Philippines. $65 \mathrm{pp}$

Anwar, E.H. 1996. Pengaruh Lama Pemberian Nannochloropsis oculata terhadap Kandungan Gizi Brachionus plicatilis. Tesis. Fakultas Biologi, Universitas Atma Jaya Yogyakarta, Yogyakarta. 64 pp.

Aslianti, T. 1994. Upaya peningkatan viabilitas larva bandeng, Chanos chanos melalui pengkayaan makanan alami. J. Penelitian Budidaya Pantai 10(3): 9-16.

Aslianti, T., Prijono, A. dan Ahmad, T. 1993. Pengaruh pemberian pakan alami dan pakan buatan terhadap kelangsungan hidup larva bandeng, Chanos chanos Forsskal. J. Penelitian Budidaya Pantai 9 (1): 81 90.

Brick, R.W. 1974. Effects of water quality, antibiotics, phytoplankton and food on survival and development of larvae of Scylla serrata (Crustacea: Portunidae). Aquaculture 3:231-244.

Fulks, W. and Main, K.L. 1991. The design and operation of commercial-scale live feeds production systems. In Fulks, W. and Main, K.L. (eds.), Rotifer and microalgae culture systems. Proceedings of a US-Asia Workshop, Honolulu, Hawaii, January 28 31, 1991. The Oceanic Institute, Honolulu, Hawaii. 3-52.

Griffith, G.W., Kenslow, M.A.M. and Ross, L.A. 1973. A mass culture method for Tetraselmis sp. a promising food for larval crustaceans. Proceeding $4^{\text {th }}$ Ann. Workshop World Maricult. Soc. 4:289-294. 
Hirata, H. 1964. Rearing of Puffer Fish, Fugu rubripes rubripes. Yoshoku 1(11):34-37

Hirata. H. 1979. Rotifer culture in Japan. Spec. Publ. Eur. Maricult. Soc. 4:361-375.

Hirata, H. and Mori, Y. 1967. Mass Culture of Marine Rotifer B. plicatilis, Fed with Bread Yeast. Saibaigyogyo 5:36-40.

Hirayama, K. and Watanabe, K. 1972. Fundamental studies of rotifers for its mass culture. IV. Nutritional effect of yeast on population growth of rotifer. Bull. Jap. Soc. Sci. Fish. 39(11):1129-1133.

Hudinaga. M. and Kittaka. J. 1966. Studies on food and growth of larval stages of a prawn P.japonicus with reference to the application to practical mass culture. Inform. Bull. Plankt. Soc. Jap. (13):83-94.

Kanazawa, A. 1985a. Microparticulate diets. In Y. Yone (ed.), Fish nutrition and diets. Suisangaku Ser. 54, Koseisha-Koseikaku, Tokyo.99-110.

Kanazawa, A. 1985b. Nutrition of penaeid prawns and shrimps. In Proceedings of the First International Conference on the Culture of Penaeid Prawns $/$ shrimps, Iloilo City, Philippines, 1984. SEAFDEC, Aquaculture Department, Iloilo, Philippines. 123. 130.

Kanazawa, A., Teshima, S. and Sakamoto, M. 1985. Effects of dietary lipids, fatty acids, and phospholipids on growth and survival of prawn (Penaeus japonicus) larvae. Aquaculture 50:39-49.

Kawano, T. 1968. On the culture of marine yeast, Zygosaccharomyces marinus, as the food for the larvae of marine animals. The Aquaculture 15:5965.

Kitajima, C., Fujita, S., Oowa, F., Yone, Y. and Watanabe, T. 1979. Improvement of dietary value for red sea bream larvae of rotifers, Brachionus plicatilis, cultured with baker's yeast, Saccharomyces cerevisiae. Bull. Jap. Soc. Sci. Fish. 45:467-471.

Kongkeo, H. 1991. An overview of live feeds production system design in Thailand. In W. Fulks and K.L. Main (eds.), Rotifer and microalgae culture systems. Proceedings of a US-Asia Workshop, Honolulu, Hawaii, January 28-31, 1991. The Oceanic Institute, Honolulu, Hawaii. 175-186.

Lim, L.C. 1991. An overview of live feeds production systems in Singapore. In W. Fulks and K.L. Main (eds.), Rotifer and microalgae culture systems. Proceedings of a US-Asia Workshop. Honolulu, Hawaii, January 28-31, 1991. The Oceanic Institute, Honolulu, Hawaii. 203-220.

Lubzens, E. 1987. Raising rotifers for use in aquaculture. Hydrobiologia 147:245-255.

Lubzens, E., Tandler, A. and Mainkoff, G. 1989. Rotifers as food in aquaculture. Hydrobiologia 186/187:387400.

Motoh, H., de la Pena, D. and Tampos, E. 1977 Laboratory breeding of the mud crab, Scylla serrata (Forskal) through the zoea and megalopa stages to the crab stage. SEAFDEC Quarterly Research Report 1(4):14-18.
Oka, M. 1967. Studies on Penaeus orientalis Kishinouye. VI. Some influence on metamorphosis. growth and feeding inclination. Bull. Fac. Fish. Nag. Univ. (23):89-100.

Pechmanee, T. and Assavaaree, M. 1993. Nutritional value of rotifer, Brachionus plicatilis, fed with emulsified oils rich in $n-3$ HUFA. Proceeding of the Seminar on Grouper Culture, Songkhla, November 30-December 1, 1993. National Institute of Coastal Aquaculture, Department of Fisheries, Thailand. 63-67.

Pie, G.G. 1991. The design and operation of a largescale rotifer culture system at a Sung.Ji Industry Farm, South Korea. In Fulks, W. and Main, K.L. (eds.), Rotifer and microalgae culture systems. Proceedings of a US-Asia Workshop, Honolulu, Hawaii, January 28-31, 1991. The Oceanic Institute. Honolulu, Hawaii. 113-118.

Purba, R. 1995. Peningkatan gizi rotifera pakan larva ikan kerapu macan. Warta Penelitian dan Pengembangan Pertanian 17(1):4-6.

Redjeki, S., Purba, R. dan Imanto, P.T. 1993. Pengkayaan rotifera untuk meningkatkan pertumbuhan dan kelangsungan hidup larva kakap putih (Lates calcarifer). J. Penelitian Budidaya Pantai 9(5):65-75.

Sato, V. 1991. The development of a phytoplankton production system as a support base for finfish larval rearing research. In W. Fulks and K.L. Main (eds.), Rotifer and microalgae culture systems. Proceedings of a US-Asia Workshop, Honolulu, Hawaii, January 28-31, 1991. The Oceanic Institute. Honolulu, Hawaii. 257-274

Sumiarsa, G.S., Ahmad, T. dan Prijono, A. 1994 Aplikasi teknik produksi benih ikan bandeng pada panti benih skala kecil : prospek dan kendala. Makalah pada Seminar Hasil Penelitian dan Pengembangan Perikanan Sulawesi Selatan, Maros. 5-7 Mei 1994. 18 pp.

Sumiarsa, G.S., Makatutu, D. dan Rusdi, I. 1996 Pengaruh vitamin $B_{10}$ dan pengkayaan fitoplankton kepadatan tinggi terhadap kepadatan dan kualitas rotifer (Brachionus plicatilis). Jurnal Penelitian Perikanan Indonesia 2(2):30-36.

Sutarmat, T. dan Ismi, S. 1996. Perbedaan lama pengkayaan Nannochloropsis oculata terhadap kandungan asam lemak rotifer (Brachionus plicatilis). Jurnal Penelitian Perikanan Indonesia 2(2):63-67

Tamaru, C.S.. C.S. Lee, and H. Ako. 1991. Improving the larval rearing of striped mullet (Mugil cephalus) by manipulating quantity and quality of the rotifer, Brachionus plicatilis. In W. Fulks and K.L. Main (eds.), Rotifer and microalgae culture systems. Proceedings of a US-Asia Workshop, Honolulu, Hawaii, January 28-31, 1991. The Oceanic Institute, Honolulu, Hawaii. 89-104.

Theilacker, G.H. and Mc Master, M.F. 1971. Mass culture of the rotifer, Brachionus plicatilis and its evaluation as a food for larval anchovies. Mar. Biol. 10(2):183-188. 
Villegas. C.T. 1990. The effects on growth and survival of feeding water fleas (Moina macrocopa Straus) and rotifers (Brachionus plicatilis) to milkfish (Chanos chanos Forsskal) fry. The Israeli Journal of Aquaculture. Bamidgeh 42(1):10-17.

Watanabe, T., Kitajima. C. and Fujita, S. 1983. Nutritional value of live organisms used in Japan for mass propagation of fish: a review. Aquaculture 34:115-143.

Wilson, R.P. 1989. Amino acids and protein. In Halver, J.E. (ed.), Fish nutrition. Academic Press, Inc., San Diego. 111-151.
Yang, W.T. 1971. Preliminary report on the culture of stone crab. Proceeding of $2^{\text {nd }}$ Ann. Workshop World Maricult. Soc. :53-54.

Yunus, Suwirya, K., Kasprijo, dan Setyadi, I. 1996. Pengaruh pengkayaan rotifer (Brachionus plicatilis) dengan menggunakan minyak hati ikan cod terhadap sintasan larva kepiting bakau ( $S$ cylla serrata). Jurnal Penelitian Perikanan Indonesia $2(3): 38-45$. 